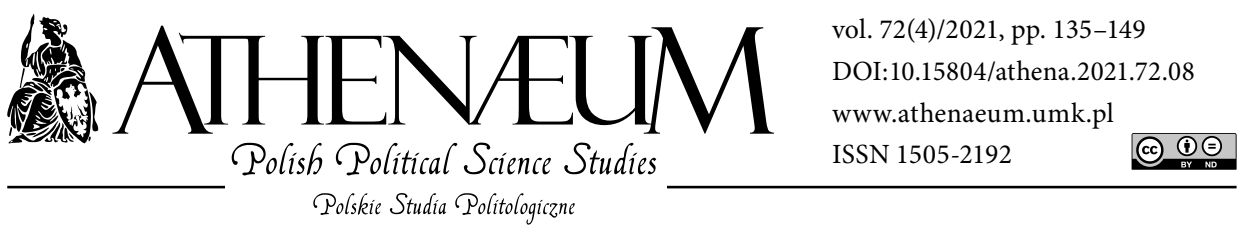

\title{
THE CHINESE DIASPORA IN NORTH KOREA: SELECTED ASPECTS
}

\author{
DIASPORA CHIŃSKA W KOREI PÓŁNOCNEJ - \\ WYBRANE ASPEKTY
}

\author{
Nicolas Levi*
}

\begin{abstract}
North Korea was always considered as a strategic partner for China. Mao Zedong described the relation of his country with North Korea as follows: "If the lips are gone, the teeth will be cold", a reference to the strategic importance of the North as a geographical security buffer. Later, in spite of the closed nature of North Korea, Kim Ilsung visited China more than forty times. North Korea, a country considered to be homogeneous, seen from the outside but perhaps also from the inside, is confronted with a little-known cultural, linguistic and religious diversity. The major economic crisis in North Korea of the $1990^{\text {s }}$ have led its authorities to rethink the advantages of its unknown heterogeneity. The main component of its heterogeneity is the Chinese diaspora, which migrated, through several waves, starting from the 1880s. This vibrant but limited in terms of number Chinese diaspora was initially recognized, but also discriminated, and due to
\end{abstract}

\begin{abstract}
Korea Północna była zawsze uważana za strategicznego partnera Chin. Mao Zedong opisał stosunki swojego kraju z Koreą Północną w sposób następujący: „Jeśli usta znikną, zęby będą zimne”, nawiązując do strategicznego znaczenia Północy jako geograficznego bufora bezpieczeństwa. W późniejszym okresie, pomimo zamkniętego charakteru Korei Północnej, Kim Ir Sen odwiedził Chiny ponad czterdzieści razy. Korea Północna, kraj uznawany za jednorodny, widziany z zewnątrz, ale może także od wewnątrz, boryka się z mało znaną różnorodnością kulturową, językową i religijną. Poważny kryzys gospodarczy w Korei Północnej w latach 90. XX wieku skłonił jej władze do ponownego przemyślenia zalet jej nieznanej heterogeniczności. Głównym składnikiem tej heterogeniczności jest chińska diaspora, która emigrowała w kilku falach, począwszy od lat 80. XIX wieku. Ta prężna, choć ograniczona liczebnie chińska diaspora od początku była
\end{abstract}

\footnotetext{
* Polish Academy of Sciences, Institute of Mediterranean and Oriental Cultures.
} 
the economic context of the 1990s, recognized as a strength of the North Korean economy.

Keywords: Chinese schools in North Korea; Hwagyos; Overseas Chinese; Sino-North Korean relations dostrzegana, ale też dyskryminowana, natomiast dopiero ze względu na kontekst gospodarczy lat 90. ubiegłego stulecia uznana została za mocną stronę północnokoreańskiej gospodarki.

Słowa kluczowe: chińskie szkoły w Korei Północnej; Hwagyos; zamorscy Chińczycy; stosunki chińsko-północnokoreańskie

\section{INTRODUCTION}

North Korea ${ }^{1}$ was always considered as a strategic partner for China. Mao Zedong described the relation of his country with North Korea as follows: "If the lips are gone, the teeth will be cold", a reference to the strategic importance of the North as a geographical security buffer. Later, in spite of the closed nature of North Korea, Kim Il-sung visited China more than forty times (Kim Pyong-il, 2003, p. 18).

North Korea, a country considered to be homogeneous, seen from the outside but perhaps also from the inside, is confronted with a little-known cultural, linguistic and religious diversity. The major economic crisis in North Korea of the $1990^{\text {s }}$ have led its authorities to rethink the advantages of its unknown heterogeneity. The main component of its heterogeneity is the Chinese diaspora, which migrated, through several waves, starting from the 1880s. This vibrant but limited in terms of number Chinese diaspora was initially recognized, but also discriminated, and due to the economic context of the 1990s, recognized as a strength of the North Korean economy. From the historical perspective, it value became recognized to a large extent, which provides a global added value to the whole North Korean society. Overseas Chinese in North Korea have also exclusive rights which allow its members to enjoy an extensive freedom in comparison to North Korean citizens, but also to participate in the defection process of North Korean individuals. The elements mentioned above will be extensively discussed in the following research paper. By definition, Hwagyos in North Korea cannot be considered as minority as they do own the Chinese nationality.

\footnotetext{
1 The official name of North Korea is the Democratic People's Republic of Korea.
} 


\section{DEFINITION}

Overseas Chinese are people of Chinese birth or descent who live outside the People's Republic of China. In this case, a member of a small community of ethnic Chinese who permanently reside in North Korea is called a Hwagyo. Hwagyo means Chinese staying in Korea while retaining citizenship of the People's Republic of China. Pukhanhwagyo (북한화교) is the denomination for Chinese people living in North Korea, and Hangukhwagyo (한국화교) for those living in South Korea. Hwagyos are Chinese in terms of ethnicity and citizenship. For simplification reasons, we will use the terms of Hwagyos for Chinese living in North Korea.

James Tudor, an American specialist on North Korean issues, speaks about 8,000 up to 10,000 people living in North Korea as of the $2000^{\text {s }}$ (Tudor \& Pearson, 2015, p. 173). Hwagyos live mostly in Pyongyang and in the areas near the Chinese border like Sinuiju and Chongjin. In spite of a limited number, they have a disproportionate role in the North Korean economy.

This community emerged in the Korean Peninsula in the 1880s. Most early migrants came from Shandong province on the east coast of China (Hisako, 2014, p. 43); many of them and their descendants have emigrated to South Korea, however there is also a small community of Chinese citizens in North Korea. The Pyongyang Governor-General's Statistical Yearbook in 1927 indicated that around 50 thousand Chinese were living on the Korean Peninsula. Approximately 29 thousand people lived in the Northern Part of the Peninsula and 21 thousand in the southern part of the country. For instance, as of 1938, 12\% of the population of Sinuiju, a North Korean city localized at the border with China, was Chinese. Meanwhile, the total number of habitants in this city was 52,384 people (Dormels, 2014, p. 131). Furthermore, according to the 1942 census, 82 thousand Chinese lived in the Korean Peninsula. 69 thousand in the northern part and 14 thousand in the southern part of the Peninsula (Kim Ju-hwan, 2012, p. 168). Immediately after the Second World War, this data has slightly decreased, as 60 thousand were living in the northern part of the Peninsula and 20 thousand in what we may refer to the geographical area of South Korea. Some Chinese and Chinese Koreans moved also to North Korea during the period of the Cultural Revolution in China (1966-1976) as North Korea was the envy of average Chinese (Tudor \& Pearson, 2015, p. 173; Masaji, 2017, p. 132).

Unfortunately, during this dark period, Chinese Koreans were highly discriminated in China, four thousands of them were murdered in the Yanbian Korean 
Autonomous Prefecture (Bayer \& Dziak, 2006, pp. 116-118). Hwagyos were also highly discriminated during these period, making it the darkest moment in their history in North Korea (Pak Jong-chol, 2012, p. 7).

These Hwagyos in North Korea constitute the only group of foreigners who are allowed to live inside North Korea for an indefinite period. They can take up employment while being able to more or less freely move around the place. They are Chinese nationals, permanently residing in North Korea. They may travel abroad with up to three hundred kilograms of luggage, and live under almost no control of the North Korean regime. Some of the Hwagyos work also in the tourism industry, where they serve Chinese tourists groups coming to North Korea (Kim Jun-ho, 2018). They do have somewhat greater freedoms, such as the right to own an unsealed radio that only tune to North Korean stations (as long as they do not listen to foreign stations in the presence of North Koreans). Hwagyos are officially recognized by the Ministry of Foreign Affairs of China as "overseas Chinese, carrying Chinese passports and living in DPRK" (Foreign Ministry..., 2004). As of 2020, there are around 5 thousands Hwagyos in North Korea living mainly in Pyongyang, Chongjin, Sinuiju and in the county of Kanggye (Kim Jun-ho, 2019).

\section{THE HISTORY OF THE HWAGYOS IN NORTH KOREA}

Despite the tens of thousands of Chinese in North Korea, their political rights were limited in the 1940 and 1950s. For instance, the North Korean government did not distribute farmland to Chinese people after the land reform opening of 1946 (Kim Ju-hwan, 2012, p. 168). Furthermore, Hwagyos could not belong to the Workers' Party of Korea or advance in the military or the civil bureaucracy. During the Korean War, the North Korean army was able to rely not only on the Chinese People's Volunteer Army, but was also directly recruiting Hwagyos.

Due to the difficult economic context related to the Korean War, Chinese entities from the mainland and Hwagyos were allowed to participate in extensive agricultural projects starting from March 1958, especially vegetable cultivation. The majority of Hwagyos managed 114 Joint Ventures with North Korean partners through diversified projects such as the Pyongyang Overseas Chinese Oil Products Union (Pyeongyanghwagyoyujijepumpeuldongjohap - 평양화교유지제 품플동조합). The significance of these Hwagyos was due to several factors. First, owning the Chinese citizenship and under the principle of the close friendship 
between China and North Korea, they were considered as the key-driver of the Sinicization of the North Korean economy. Secondly, the Sino-North Korean Mutual Aid and Cooperation Friendship Treaty signed on the July 11, 1961 boosted the bilateral affairs. Thirdly, the destructions caused by the Korean War urged the launching of quick solutions toward the destructed North Korea. China was the biggest donor of technical and economic assistance to North Korea after this conflict (Kim Pyong-il, 2003, p. 17). Hwagyos were hired in various fields of the economy, from mining fields to commercial positions, not only on low-profile positions but also with managerial engagements.

The population of Hwagyos in North Korea was estimated at 14,351 persons (in 3,778 households) in 1958 , shrinking to a mere 6,000 by 1980 , as they had been encouraged by the North Korean government to leave for China in the $1960^{\text {s }}$ and $70^{\text {s }}$ due to their ethnic origin, not compatible with the purity of the Korean race. In 1959, Kim Il-sung visited the Pyongyang Hwagyu Daesong Rural Cooperative and after his visit, the Chinese embassy in Pyongyang noted that pressure from North Korean authorities to 'Koreanize' the Chinese population, through an intensive learning of the Chinese language, fiercely increased (Song $\mathrm{Hu}$-jang, 2017). Meanwhile, the North Korean government forced Chinese students studying at the Kim Il-sung University to participate in political and social events praising also Kim Il-sung (Song Hu-jang, 2017). Then North Korean authorities officially suggested Hwagyos to choose between three options: first, leave for China without a right to return; second, become a North Korean citizen and forsake their Chinese passport; third, loose their privileges but be able to have an access to the Public System of Distribution, which distributes basic goods to the North Korean population. The whole situation was partially also due to the behavior of Chinese people educated in North Korea, who promoted works of Mao Zedong in Pyongyang, something that was considered inconvenient by North Korean authorities. They had a low standard of living, could not join the WPK (Workers' Party of Korea) and thus were limited in terms of career opportunities (Tudor \& Pearson, 2015, p. 173). Some older North Korean even remember Hwagyos as being beggars (Tudor \& Pearson, 2015, p. 173) or living as homeless (Pak Jong-chol, 2012, p. 6). The situation of Hwagyos changed after the visit of Zhou Enlai to Pyongyang in 1971. In exchange of a financial support, North Korean authorities allowed former Hwagyo to restore their citizenship. The majority of Hwagyos were willing to do that and submitted necessary documents to North Korean authorities and to the Chinese Embassy in Beijing. Later they were restored their citizenship. The situation of the Japanese minority in 
North Korea was different, they were still considered in the $1970^{\text {s }}$ as citizens of the lowest social level in North Korea due to their economic uselessness (Masaji, 2017, p. 60). That is also why Hwagyos created association of Overseas Chinese in each city where they lived, for instance, the association of Hwagyos of Chongjin (Cheongjin hwagyohyeopoega jugwan - 청진 화교협회가 주관), one of the North Korean cities where the population of Hwagyos is the highest.

A few years later, the economic position of Hwagyos drastically changed, from beggars in the $1960^{\text {s }}$ to money masters (Dongju - 동주) in the $2000^{\text {s }}$ for the following reasons.

First, in the 1980s, they were allowed to visit their relatives in China, who could support their economic situation (Tudor \& Pearson, 2015, p. 174). Secondly, the economic crisis in North Korea which started in the mid-1980s boosted the position of Hwagyos in the North Korean economy. The failure of the Public System of Distribution and utilities problems urged the population to find solutions excluding the government, which could not support the main population. That is why Hwagyos were allowed to travel abroad, and participate in the important and profitable export-import business. The situation also changed for the Japanese minority in North Korea, which saw its own situation improved (Masaji, 2017, p. 106) in the same period of time. Hwagyos also established branches of Chinese companies based in North Korea specialized in the trade with North Korea. Some of these companies are functioning under the auspices of the WPK (Kim Byung-yeon, 2017, p. 138). Hwagyos were also the first among the North Korean population to be allowed to be sole owners of houses of cars, which was strictly forbidden by North Korean standards (Pak Jong-chol, 2012, p. 14). In 2008, the economy of North Korea switched from a dollarisation to a yuanisation, making the Chinese currency the most used among vendors. This also stimulated the economic position of Hwagyos in North Korea (Pak Jong-chol, 2012, p. 18). However, since a few years, more and more North Korean Foreign Trade companies established branches in China Mainland and act as competitors to Hwagyos, which made their position less profitable than in the past (Jon Kyung-ung, 2018).

At this time, it is the Chinese people in North Korea who share the essential basic consumer goods (such as medical drugs, shoes, and garments) that North Koreans need. Hwagyos became the main retail importers of North Korea, bringing North Korean mushrooms to China and coming back with necessities goods to North Korea. The city of Chongjin, considered as the third largest city of North Korea with a population of a half million of habitants, became a relevant trade center for Hwagyos. Living there for more than hundreds of years, due 
to a specific legislation mentioned earlier and to a strategical localization, 90 kilometers from the Chinese border, Hwagyos of Chongjin participated in major changes in the North Korean economy. These people were able to bring and trade Chinese products to the Chongjin population. Thus, Chongjin became the trendiest city in North Korea (Dormels, 2014, p. 310) due to its access to foreign products from China, but also Japan. Except daily products, Hwagyos also started to bring to North Koreans electrotechnical devices such as automotive spare parts, water pumps, etc., however due to technical aspects (size and weight), this category of business was managed by wealthier Hwagyos with logistical capabilities. These same wealthier Hwagyos were able to use the fastest but also the most expensive shipping rates through Dandong/Sinuiju instead of Changbai/Hyesan (Jon Kyung-ung, 2018).

Therefore, later in the 2000s, the North Korean authorities also started to have a friendlier attitude toward richer Chinese people in North Korea in order to attract large Chinese capital with their help. For instance, Kim Jong-il visited the North Korean embassy in Pyongyang several times, and sent letters of appreciation to the most prominent Hwagyos in North Korea. The improved position of Hwagyos in North Korea allowed them also to visit China not only for business purposes but also for leisure ones.

Among Hwagyos living in North Korea there is also a group of Chinese people who live in the mainland, but go back to North Korea once a year in order to extend their North Korean permanent residence permits (Lankov, 2016). More generally, Chinese based in North Korea used to go back to China during the Lunar New Year. Hwagyos, due to their economic function, are also qualified as people who rent passports (Hwagyo Step in to Dominate Border Trade, 2014). They participate in transporting assistance of cross-border freight between Chinese citizens and North Koreans taking a commission on these transactions. Meanwhile North Korean companies are sometimes cooperating with Chosonjok, who are ethnic Korean owning the Chinese citizenship.

\section{EDUCATION ISSUES AND THE HWAGYOS}

After 1948, Hwagyos established a network of Chinese schools and rebuilt some Chinese-language education facilities which were destroyed during the Japanese colonization (1910-1945). The first Chinese school in the Korean Peninsula was established in Seoul in 1902. Due to the limited funds of the North Korean 
regime, the founder of the Chinese schools in North Korea was the Communist Party of China. Starting from April 1949, these schools became administered by the North Korean government, which also participated in its fundings. As of 1949 , there were 3,000 pupils and 1,000 students, as well as 150 teachers in 50 Chinese elementary schools. The biggest middle school was in Pyongyang, where 300 students were enrolled, and a school in Sinuiju dealt with hundred feminine pupils. The Korean side decreased the number of Chinese students in North Korea to 2,858 people (Song Hu-jang, 2017). One of them is the Pyongyang Chinese Middle School, built in 1949, divided into four grades of elementary school and six grades of junior high school. Between 1959 and 1961, four additional Hwagyo middle schools and one Hwagyo high school were built in North Korea. The curriculum of Chinese schools included also the Korean languages and subjects related to the North Korean history. These schools were not compulsory for Hwagyos, they could also choose North Korean schools. The majority of Hwagyos based outside of Pyongyang were unfortunately forced to follow North Korean courses due to a lack of Chinese education centers for those older than twelve.

Starting from 1960, Chinese high schools were established in several cities of North Korea such as Pyongyang, Kanggye, and Chongjin, where the majority of Hwagyos lived. When the economic situation of North Korea improved and the independence path started to dominate the North Korean ideology in the early 1960s, Chinese teachers from the mainland were removed to the original localization and classes for Hwagyos were mainly taught in Korean (I Hui-song, 2019). This situation was also due to the fact that Hwagyos were not speaking Korean. Therefore, North Korean authorities queried two times Chinese educators to increase the number of lectures related to the Korean language in Hwagyo schools in 1950 and 1955, unsuccessfully till 1957 (Song Hu-jang, 2017). Despite demonstrations of Hwagyos, gradually from the mid-1960s several Chinese high schools got closed or merged with North Korean education institutions due to the uniformisation of the North Korean education system. During the Spring of 1962, the North Korean ministry of education announced that North Korean school curriculum would be enforced in the "schools for the Chinese" and all lessons would be taught in Korean (Tertitskiy, 2015b, p. 14; Song Hu-jang, 2017). Also, the North Korean government stopped providing support to the Chinese High School of Pyongyang, but on the other hand, it arranged the transfer of Hwagyo pupils to North Korean schools (Song Hu-jang, 2017), implementing also lectures of Chinese for these Hwagyos. In order to implement the New 
Course Plan, a meeting of principals of Hwagyo schools at various levels was organized in Hamheung on May 20, 1962. The New Course Plan was implemented in 1963 (Song Hu-jang, 2017). Due to the previous elements, the Chinese High School of Pyongyang shut down on October 25, 1966. The same fate was applied to other Chinese schools in North Korea in the cities of Kanggye (Jagang Province), Sinuiju (North Pyongan Province), and Chongjin (North Hamgyong Province). However, as of the late 2010s, there were still four Chinese middle schools which followed the Korean curriculum and education system (Tertiskiy, 2015a, p. 182). Three of them are located in Pyongyang (Zhōngguó..., 2018). They are fully subsidized by the Chinese embassy in Pyongyang, but also get a moral support of North Korean authorities. The Pyongyang Overseas Chinese School enrolled 60 students as of 2019 (Kim Jun-ho, 2010). In comparison, there are twenty-eight primary and four secondary Hwagyo schools in South Korea, accommodating more than 3,000 pupils (Cheng, Rosett, \& Woo, 2003, p. 168). In 1978 , due to the reform of the Chinese education system, Hwagyos were allowed to take entrance examination under specific conditions to Chinese mainland universities. Some passed their exam and started their education at the Fujian University, where every year around 10-20 Hwagyo students from North Korean were enrolled.

The Chinese embassy officials also visit regularly Hwagyo education facilities in North Korea (Zhōngguó..., 2018). Some North Korean schools use the patronage of Mao Zedong to honor some classes. On the other hand, some schools in Beijing use Kim Il-sung as a patronage. Some of Hwagyo graduates go on to Chinese universities; for example, as of 2002, the Jinan University in Guangzhou had over 100 Overseas Chinese students from North Korea. From a different perspective, international weddings in North Korea started to be banned from 1965 in order to maintain the homogeneity or purity of the Korean race, but Hwagyos continued to be allowed to marry North Korean women (Levi, 2018, p. 133). However their North Korean spouses cannot obtain the Chinese nationality (Tudor, 2018, p. 211).

\section{DIFFICULTIES AND CHALLENGES MET BY THE HWAGYOS}

After the Chinese government came out in support of United Nations Security Council Resolution of 1874 in June 2009, which imposed sanctions on North Korea, it was reported that North Korean surveillance and repression of Chinese 
residents had increased, and many had chosen to avoid making trips out of the country to avoid scrutiny. In the mainland, Chinese banks refuse to open accounts to Hwagyos (Jon Kyung-ung, 2019) and limit the access to existent accounts by limiting the amount of deposit withdrawal due to suspicions of money laundering.

Some Hwagyos use their status to escape from North Korea (Jon Kyung-ung, 2015). In some situations, these Hwagyos serve as intermediary to those escaping from North Korea. They do bring money to brokers based in China (Tudor \& Pearson, 2015, p. 30). Some Hwagyos, at least ten of them, where used by the South Korean secret services to obtain information about the North Korean leadership, military secrets, or spread South Korean movies to the North Korean population (Namjoseonjeongbowon..., 2015).

Sometimes some Hwagyos try to defect to South Korea, such as four North Korean Hwagyos in 2019. These persons are not considered as North Korean defectors under the Act Related to the Protection of Defecting North Korean Residents and Support of Their Settlement regardless of owning a North Korean alien registration card. Usually these Hwagyos prepared precisely their defection, initially sending a Hwagyo to China dealing with the defection procedure (아버지가 화교인 일가족 탈북해 제3국에 안착). The main problem is related to the wives of these Hwagyos who own the North Korean nationality. They do not have the Chinese one and therefore are considered as illegal migrants in China. Therefore, these women may be deported to North Korea while being caught in China by Chinese customs officials. On the side, even if these mixed families defect to a third country, only the women and children may obtain the South Korean nationality as their husbands are Hwagyos and do not fulfill the criteria of the Act Related to the Protection of Defecting North Korean Residents and Support of Their Settlement. Until recently, Hwagyos based in North Korea were not able to obtain easily the Hukou (Chinese Identity Card), they were supposed to prove that they were financially independent and were forced to live three years in China Mainland with their Hwagyo status. This element did not motivate Hwagyos to come back to China Mainland and rather motivated them to defect to a third country. However the law was changed in 2019. In a close future we can indeed observe a major return of Hwagyos to China Mainland. Generally speaking, those who would remain in North Korea are usually Chinese husbands who have North Korean spouses and children.

Also some Chinese people living in North Korea, who are Chinese nationals, often come to South Korea under the control of the Chinese Communist Party 
and the North Korean Workers' Party, and spy on illegal activities (Tertiskiy, 2015b, p. 180). Although they are North Koreans in China, they often disguise themselves as Korean-Chinese when they enter South Korea (Jon Kyung-ung, 2015). On the other side, some North Korean Hwagyos, such as Yu U-song and his brother Yu Ga-ryo were supposed to divulgate the identity of hundreds of North Korean defectors based in South Korea to the North Korean Security Agency. The trial finally acquitted them (Jin Kyong-ung, 2017).

Concerning the point mentioned in the previous paragraph, it can be remarked that when Hwagyos are less needed by North Korean authorities, or when they want to pressure the Chinese government, the approach of Pyongyang may drastically change. For instance, as of 2020 , it has been demanded from Hwagyos to participate in political events in North Korea (Kim Ji-eun, 2020). If they do not attend these events, they may be forced to fines. Hwagyos, before getting back to China, got some preeducation sessions about the code of conduct while staying in China, not to mention the internal situation of North Korea, and not to disclose the market price and price fluctuations of other products other than the goods they do sell directly (Kim Ji-eun, 2017). Some Hwagyos were also allegedly charged with espionage. In spite of these pressure, as of 2019, the majority of male Hwagyos remain still in North Korea because their spouses are North Korean citizens and their children obtained the North Korean citizenship (Kim Jun-ho, 2018). However, there is a trend where Hwagyos tend to relocate to China, especially to Dandong, a border city of China to North Korea (Lankov et al., 2015, p. 23).

Within the last forty years, North Korean authorities are believed to have tightened their nationality management policies for Chinese people from the Kim Il-sung regime to the Kim Jong-il regime to the present Kim Jong-un regime. In the Kim Il-sung regime, if only one of the parents was Chinese, the second generation could register as North Korean or Chinese nationality as his parents wanted (Kim Jun-ho, 2016). As of now, they are registered as North Koreans. Since 2015, and probably due to the willingness to gather foreign currencies, the North Korean authorities reported that young Hwagyos who had the North Korean nationality were able to acquire the North Korean alien card. First these citizens must give up their North Korean citizenship, if they are more than two years old. Such process cost in the past 10,000 USD. Now the amount decreased to 5,000 USD. This amount represents still a large sum for Chinese based in North Korea. They usually ask their relatives for financial support. Meanwhile ethnics Koreans based in China obtain the Chinese nationality (Kim Si-joong, 2003, p. 103). 


\section{CONCLUSION}

The aim of the paper was to present the diaspora of Hwagyos in North Korea in a historical perspective from 1949 till 2019. This population initially immigrated to the country in the $19^{\text {th }}$ century, although the majority came to Korea during the 1927-1949 Chinese Civil War. These Overseas Chinese have a specific status in North Korea, which is highly dependent on the nature of relations between China and North Korea. On the one hand, the North Korean authorities gave unprecedented possibilities to this Chinese diaspora while facing economic crisis. On the other hand, Hwagyos might participate in the destalinization of the North Korean regime. In 1966, Hwagyos expressed their dissatisfaction toward the North Korean leadership by praising publicly Mao Zedong.

We can assess that within two or three decades, the entire community which first appeared in the late $19^{\text {th }}$ century will have left. The young people are already moving to China, often keeping their residence permits for the sake of business, and the older people who still stay in North Korea are going to follow them eventually. Theoretically, even now each Hwagyo can change their passport to a North Korean whenever they please, but they have no incentive to do so. Such pessimistic view is based on the instability of the North Korean regime and the lack of incentives the North Korean government is offering Hwagyos. Such behavior can be justified through the nationalist pattern of the government model of North Korea.

Although this research paper provides some crucial insights, unfortunately it is not without limitations. First, there is a lack of recent information on some social indicators at the domestic source level due to the COVID-19 Pandemic. Based on the extensive - but naturally limited - research of the author, it is striking to notice that Hwagyos are never mentioned in the North Korean press or official propaganda documents (including Kim Il-sung and Kim Jong-il's writings, propaganda magazines, etc.). It would confirm the theoretical supremacy of the Korean nation toward other minorities present in North Korea. In any case, this supremacy cannot be justified as we discussed the crucial role of the Hwagyos in the progress of the North Korean economy after the collapse of the Public System of Distribution.

Secondly, the nature of the North Korean state prevents from producing reliable statistics. Therefore it is generally impossible to make any comparison with other minority groups living in North Korea such as the Jaegaseung people, Japanese or Russian social groups. These elements influenced also the descriptive 
nature of this research paper. Thirdly, one of the main limits of this research is its attempt to analyze a relatively long period. The socialization of Hwagyos in North Korea was a dynamic process which is still changing, and I guess that it may be also a thriving question to focus on a specific period, for instance, the integration of the Hwagyos after the Chinese government came out in support of the United Nations Security Council Resolution in June 2009. That is why some of these aforementioned research limitations may provide opportunities for future research on Hwagyos in North Korea. I would also suggest to discuss and verify how Hwagyos are represented in the North Korean literature, for instance, in a defined period or within the framework of some selected publications. In spite of the nature of the North Korean state, there are some clear allusions to foreign cultures in the North Korean culture which gives some hope to define the image of Hwagyos in the available literature of this reclusive but fascinating country.

\section{REFERENCES:}

2018 Nián 8 yuè 30 rì, zhù cháoxiăn dàshì lì jìnjūn zŏufăng pingrăng dì sān zhōngguó rén xiăoxué, cháoxiăn huáqiáo zhōngyāng liánhé huì wěiyuán zhăng sài tiějūn, pingrăng shì wàishì jú júzhăng lì shànhào dèng péitóng (2018, August 30). Retrieved October 10, 2018 from: http://cxhq.info/read.php?tid=6731.

Bayer, J., \& Dziak, W.J. (2006). Korea \& Chiny. Przyjaźń i wspótpraca, rywalizacja $i$ konflikty. Vol. 2: Gospodarka i granice. Warszawa: ISP PAN.

bughan hwagyowa jogyo [hoengseolsuseol/gujalyong] (2019, July 27). Retrieved December 10, 2019 from: http://www.donga.com/news/article/all/20190727/96718627/1.

bukhanŭi hwagyohyŏnhwang (2001, August 8). Retrieved February 10, 2020 from: https://bit.ly/32qYz3H.

Cheng, L., Rosett, A., \& Woo, M. (Eds.) (2003). East Asian Law: Universal Norms and Local Cultures. New York: Routledge.

Dormels, R. (2014). North Korea's Cities: Industrial Facilities, Internal Structures and Typification. Seoul: Jimoondang.

Foreign Ministry Spokesperson Kong Quan's Press Conference on April 272004 (2004, April 27). Retrieved January 10, 2018 from: http://www.chinaembassy.bg/eng/dtxw/ t132094.htm.

Hisako, K. (Ed.) (2014). Migration and Diaspora: Exegetical Voices of Women in Northeast Asian Countries. Tokyo: Society of Biblical Literature.

Hwagyo Step in to Dominate Border Trade (2014, July 29). DailyNK.com. Retrieved December 8, 2019 from: https://www.dailynk.com/english/hwagyo-step-in-todominate-border/. 
I, H.S. (2019, September 10). [pukhan eochewa oneul] 1966 nyeon pyeongyang chungkukin hwagyo panlan (?) sageon. Retrieved November 13, 2019 from: https://bit. ly/2QVgSfz.

ijinjwin jujoseon jung-gugdaesa, dongpyeong-yangjeljunghaggyo 'maojjeodung ban' bangmun (2016, July 28). Retrieved May 5, 2019 from: http://kr.people.com.cn/ n3/2016/0728/c208059-9091916.html.

Jon, K.U. (2015, February 5). talbugja, 100 myeong guchulhan 'mingan cheobbowon' mannalyeomyeon. Newdaily.co.kr. Retrieved November 11, 2019 from: http://www. newdaily.co.kr/site/data/html/2015/02/05/2015020500185.html.

Jon, K.U. (2017, November 4). Unhaengteul 'bukhanhwagyo' kyechwakaeseol keocheol “dwaeui kkeunap'ul”. Newdaily.co.kr. Retrieved February 21, 2020 from: http://www. newdaily.co.kr/site/data/html/2017/11/04/2017110400005.html.

Jon, K.U. (2018, March 8). Bug, gug-yeong oehwabeol-ie hwagyo bottalisang millyeo... 5 manmyeong $\rightarrow 3$ cheonmyeong jul-eo. Newdaily.co.kr. Retrieved February 21, 2020 from: http://www.newdaily.co.kr/site/data/html/2018/03/08/2018030800030.html.

Jon, K.U. (2019, April 8). Bughan nae 'hwagyo bottalisang'i daebugjejae wiban jubeom? Newdaily.co.kr. Retrieved January 6, 2020 from: http://www.newdaily.co.kr/site/ data/html/2019/04/08/2019040800221.html.

Kim, B.Y. (2017). Unveiling the North Korean Economy: Collapse and Transition. Cambridge: Cambridge University Press.

Kim, J.E. (2017, August 1). Bug, hwagyo ibdansog sajeongyoyug silsi. rfa.org. Retrieved February 21, 2020 from: https://www.rfa.org/korean/in_focus/ne-je08012017090514.html.

Kim, J.E. (2020, January 15). Ethnic Chinese Residents of North Korea Penalized for Failing to Participate in Political Events. rfa.org. Retrieved January 30, 2020 from: https://www.rfa.org/english/news/korea/nk-hwagyo-political-event-absencepunishment-01152020095314.html.

Kim, J.H. (2010, September 13). pyeong-yang hwagyohaggyo, lyugyeonghotel gongsa ping-gyelo ijeon. rfa.org. Retrieved September 3, 2018 from: https://www.rfa.org/ korean/in_focus/chiness_nkorean-09132010154725.html.

Kim, J.H. (2012). Bughan gyeongjehwaldong dong-in-euloseoui bughan hwagyoui yeoghal. segyejiyeog-yeongunonchong, 30(1).

Kim, J.H. (2016, June 20). Bug hwagyojanyeodeul-ui jung-gug gugjeog chwideug gil yeol-eojwo. rfa.org. Retrieved October 1, 2018 from: https://www.rfa.org/korean/ in_focus/ne-ch-06202016095224.html.

Kim, J.H. (2018, March 7). Bug geoju hwagyodeul gajogbuyang wihae jung-gug-eseo magnodong. rfa.org. Retrieved October 10, 2019 from: https://www.rfa.org/korean/ in_focus/food_international_org/chinessnkorean-03072018084520.html.

Kim, J.H. (2019, February 18). Jung, bughan-eseo ijuhan hwagyodeul-ui hogu chwideug jogeon keuge wanhwa. rfa.org. Retrieved February 27, 2020 from: https://www.rfa. org/korean/in_focus/ne-ch-02182019102549.html. 
Kim, J.H. (2019, June 7). abeojiga hwagyoin ilgajog talbughae je3gug-e anchag. rfa.org. Retrieved February 21, 2020 from: https://www.rfa.org/korean/in_focus/ne-ch06072019091810.html.

Kim, J.H. (2019, July 8). Bug, hwagyodeul-e gabsbissan pyeong-yangdanchegwangwang gang-yo. rfa.org. Retrieved February 18, 2020 from: https://www.rfa.org/korean/ in_focus/food_international_org/pytour-07082019100526.html.

Kim, P.I. (2003). Historical Dictionary of North Korea. Lanham: The Scarecrow Press.

Kim, S.J. (2003, January). The Economic Status and Role of Ethnic Koreans in China. In: C.F. Bergsten, \& I. Choi (Eds.). The Korean Diaspora in the World Economy. Special Report, 15 (pp. 101-130). Washington: Peterson Institute for International Economics.

Lankov, A. (2016, September 15). "Ms. Wang" and the Curious Case of North Korea's Chinese Citizens: Understanding the DPRK's Chinese Minority and What Their Future Holds. Retrieved April 13, 2019 from: https://www.nknews.org/2016/09/ms-wangand-the-curious-case-of-north-koreas-chinese-citizens/.

Lankov, A., Driscoll, J., Lee, J.S., \& Steele, L. (2015). Life on the North Korea Borderlands: A Collection of Essays by NK News Contributors. Seoul: NK News.

Levi, N. (2018). Nic nie wiem o Korei Pótnocnej. Warszawa: Asian Century.

Masaji, I. (2017). A River in Darkness: One Man's Escape from North Korea. Seattle: Amazon Crossing.

Namjoseonjeongbowon gancheobdeul beomjoejinsang jabaeg-gugnaeoegijahoegyeon (2015, March 26). Seoul: Korean Central News Agency.

Pak, J.C. (2012). Gwigugjaleul tonghaeseo bon bughansahoe. Jeju Peace Institute Forum, 16.

Song, H.J. (2017, August). Ihu bughanhwagyohaggyoui lokeolhwa. Retrieved April 24, 2018 from: http://aocs.inu.ac.kr/webzine/app/view.php?wp=216.

Tertitskiy, F. (2015). bughan hwagyo gyoyug jedoui yeogsa. Journal of North Korea Studies, 3(1).

Tertitskiy, F. (2015). Exclusion as a Privilege: The Chinese Diaspora in North Korea. Journal of Korean Studies, 20(1), 177-199. DOI: 10.1353/jks.2015.0009.

Tudor, D. (2018). Ask a North Korean: Defectors Talk about Their Lives Inside the World's Most Secretive Nation. Tokyo: Tuttle Publishing.

Tudor, D., \& Pearson, J. (2015). North Korea Confidential: Private Markets, Fashion Trends, Prison Camps, Dissenters and Defectors. Tokyo: Tuttle Publishing.

Zhōngguó zhù cháoxiăn dàshǐ lǐ jìnjūn zŏufăng wèiwèn jiāngyuán dào lü cháo huáqiáo (2018, August 12). Retrieved from: http://kp.chinaembassy.org/chn/dssghd/ t1585200.htm. 